\title{
The Influence of Insulin on the Lipids in the Pulmonary Artery and the Lungs of Severely Diabetic Rats
}

\author{
A Histochemical and Chemical Study
}

\author{
A. Reinilä, H. K. Åkerblom, and V. A. Koivisto \\ Departments of Pathology and Paediatrics, University of Oulu, Oulu, and the Children's Hospital, University of Helsinki, Helsinki, Finland
}

Summary. The effect of insulin on the triglyceride deposits found in the pulmonary artery branches of streptozotocin-diabetic rats was investigated by treating the animals for two, five, nine or 14 days with insulin (3-8 units/day). Histochemical analysis showed that the triglyceride deposits in the pulmonary artery developed within three to four days after the induction of diabetes, but were not present in any animals five days from the initiation of insulin therapy. Plasma triglycerides, non-esterified fatty acids, phospholipid and total cholesterol concentrations were within the normal range within two days of the inception of insulin therapy and random plasma glucose levels were normal within five days. Analysis of lung lipids showed that after 14 days of insulin treatment the decreased content of phospholipids and the increased content of non-esterified fatty acids found in diabetic rats were also normalized. These findings suggest that insulin has an important role in the regulation of lipid metabolism in the pulmonary artery and lung tissue in the diabetic state.

Key words: Diabetes, insulin, non-esterified fatty acids, lipid metabolism, lung, phospholipids, pulmonary artery, rat, streptozotocin, triglycerides.

Lipoprotein lipase (LPL) has been identified in the aortic wall of different species $[1,2]$; little is, however, known about the hydrolysis of lipids in the pulmonary artery. The reported effects of insulin and other hormones on lipid metabolism of the arterial wall and on atherogenesis are controversial. Increased lipolytic activity has been observed in the aortic wall of alloxan-diabetic rats, and the adminis- tration of insulin reduces the activity [3]. On the other hand, a lipolytic effect of insulin in aortic tissue of experimental animals in vitro has been described [4].

Recently we reported triglyceride deposits in branches of the pulmonary artery of severely diabetic rats, not treated with insulin [5]. The first aim of the present study was to find out more exactly the time needed for the deposition of triglycerides in the pulmonary artery wall in experimental diabetes, and to establish whether insulin treatment had any effect on the lipid deposits.

A decreased synthesis of phospholipids and neutral lipids of pulmonary tissue has been noted in experimental diabetes, and insulin restores this within a short time [6, 7]. Previously [5] we showed an increased content of pulmonary non-esterified fatty acids (NEFA) and a decreased content of pulmonary phospholipids in severely diabetic rats, not treated with insulin. The second aim of the present study was, therefore, to explore the effect of insulin treatment on the lipid composition of pulmonary tissue in experimental diabetes.

\section{Material and Methods}

\section{Induction of Diabetes}

Male Sprague-Dawley rats weighing $300-350 \mathrm{~g}$ were used. Diabetes was induced with streptozotocin (Upjohn \& Co., lot $1613 \mathrm{E}$, MCM 2), $3 \mathrm{~g} / 100 \mathrm{ml}$, freshly prepared in $0.1 \mathrm{~mol} / \mathrm{l}$ citrate buffer, $\mathrm{pH} 4.5$, and injected intracardially in a dose of $65 \mathrm{mg} / \mathrm{kg}$ of body weight under pentobarbital anaesthesia [8]. Control rats received an equal volume of intracardiac buffer. Rats were fed ad libitum a commercial chow containing $53.0 \%$ carbohydrate, $20.9 \%$ protein, $4.5 \%$ fat, $3.9 \%$ fibre and the usual vitamins and minerals (Hankkija Ltd., Turku, Finland). Only severely diabetic animals were included in the study (weight loss, marked ketonuria: Ketostix ${ }^{\circledR}$ +++ , and glucosuria, $>5 \mathrm{~g} / 100 \mathrm{ml}$ by Clinitest $^{\circledR}$ ). 
Table 1. Non-fasting levels of plasma glucose, triglycerides and non-esterified fatty acids (NEFA) and the incidence of pulmonary artery triglyceride deposits in diabetic rats two, three and four days after the injection of streptozotocin $(65 \mathrm{mg} / \mathrm{kg})$, and in control rats, mean \pm SEM. For details see text

\begin{tabular}{|c|c|c|c|c|c|}
\hline $\begin{array}{l}\text { Diabetic rats } \\
\text { - Time after } \\
\text { induction of } \\
\text { diabetes } \\
\text { days }\end{array}$ & n & $\begin{array}{l}\text { Plasma glucose } \\
\mathrm{mg} / 100 \mathrm{ml}\end{array}$ & $\begin{array}{l}\text { Plasma triglycerides } \\
\mathrm{mg} / 100 \mathrm{ml}\end{array}$ & $\begin{array}{l}\text { Plasma NEFA } \\
\mathrm{mmol} / 1\end{array}$ & $\begin{array}{l}\text { Triglyceride deposits } \\
\text { in the pulmonary } \\
\text { artery, positive } \\
\text { cases }\end{array}$ \\
\hline 2 days & 15 & $280 \pm 7^{a}$ & $660 \pm 69$ & $0.81 \pm 0.05^{b}$ & $0^{c, d}$ \\
\hline 3 days & 15 & $302 \pm 6$ & $758 \pm 81$ & $1.01 \pm 0.10$ & $5^{\mathrm{c}}$ \\
\hline 4 days & 15 & $310 \pm 6^{a}$ & $850 \pm 90$ & $1.10 \pm 0.09^{b}$ & $4^{d}$ \\
\hline Control rats & 15 & $102 \pm 2$ & $165 \pm 7$ & $0.40 \pm 0.04$ & 0 \\
\hline
\end{tabular}

${ }^{\mathrm{a}} \mathrm{p}<0.01 ;{ }^{\mathrm{b}} \mathrm{p}<0.01 ;{ }^{\mathrm{c}} \mathrm{p}<0.025 ;{ }^{\mathrm{d}} \mathrm{p}<0.05$

In order to establish the length of time needed for the development of triglyceride deposits in the pulmonary artery wall, 15 nontreated diabetic rats were killed two, three and four days after the injection of streptozotocin.

\section{Insulin Treatment}

Four days after the injection of streptozotocin insulin treatment with lente insulin was initiated (Insulin Novo Lente ${ }^{\circledR}$ ). Insulin, 3-8 units, was given once a day sc. The dose of insulin was adjusted according to weight of the rats, plasma glucose concentration, and the amount of glucosuria and ketonuria, these parameters being controlled daily at $9 \mathrm{a} . \mathrm{m}$. Further groups of 15 diabetic rats were killed at two, five and nine days, and 19 rats at 14 days after the initiation of insulin treatment. The 19 non-diabetic control rats were not treated with insulin, and were killed after 14 days.

Handling of Blood and Tissue Specimens: Blood was drawn from the retro-orbital venous plexus of non-fasting rats through a capillary tube under pentobarbital anaesthesia and collected in ice-cold ethylene-diaminetetraacetic acid (EDTA) tubes (final concentration of EDTA, $21.7 \mu \mathrm{mol} / \mathrm{l}$ ). The plasma specimens were stored at $-20^{\circ} \mathrm{C}$ until analysis. Immediately after blood sampling the animals were decapitated, the lungs removed and one lung was perfused through the pulmonary artery with $0.154 \mathrm{~mol} / 1$ saline until the fluid coming from the pulmonary veins was clear. The perfusion usually lasted 5 minutes. A piece of pulmonary artery was then removed for histochemical analysis. In addition, a piece of pulmonary tissue was taken for chemical analysis from rats treated with insulin for 14 days and from the untreated control rats. Tissue specimens were frozen in liquid nitrogen and kept at $-70^{\circ} \mathrm{C}$ until analysis.

Methods: Histochemical analyses of the pulmonary artery were performed for total hydrophobic lipids (9), NEFA (10), triglycerides (11), total cholesterol (12) and phospholipids (13). The specimens of the pulmonary tissue were freeze-dried and homogenized in chloroform-methanol $(2: 1 ; \mathrm{v} / \mathrm{v})$. After the extraction of lipids (14) the total lipids were determined gravimetrically (15). The dried extract was reconstituted to $1 \mathrm{ml}$ with chloroform and analysed chemically for NEFA (16), triglycerides (17), total cholesterol (18) and phospholipids (19). Plasma glucose was measured by the method of Carrol et al. (20), with slight modifications (21), and plasma NEFA, triglycerides, total cholesterol and phospholipids were determined by the methods referred to above.
Values for the lipids of the pulmonary tissue are given as $\mathrm{mg} / \mathrm{g}$ of total lipids. Non-esterified fatty acids are given in terms of their equivalence in palmitic acid in $\mathrm{mmol} / \mathrm{l}$. The results for body weight, plasma glucose, NEFA and triglycerides are expressed as mean $\pm S E M$. The statistical significance of the differences between these mean values was calculated using Student's t-test. The difference between the proportions of triglyceride-deposit positive and negative cases was tested with the Fisher exact probability test. The differences between plasma glucose and lipid values before and after insulin treatment, and between pulmonary lipids of untreated and treated diabetic rats was tested by analysis of variance.

\section{Results}

Two days after the injection of streptozotocin the weight loss of the diabetic rats was $31 \pm 2.8 \mathrm{~g}(9.9 \pm$ $0.9 \%)$, three days after the injection $40 \pm 3.1 \mathrm{~g}(13.1$ $\pm 1.0 \%$ ), and four days after the injection $56 \pm 3.6 \mathrm{~g}$ $(18.9 \pm 1.2 \%)$. Ketonuria and glucosuria were marked within two days after the induction of diabetes.

\section{Time Course of Deposition of Triglycerides in the Pulmonary Artery}

Two days after the induction of diabetes no triglyceride deposits were seen in the walls of the pulmonary artery branches, but after three days deposits were found in five out of 15 animals $(\mathrm{p}<0.025)$ (Table 1). In rats killed four days after the induction of diabetes, significant deposition of triglycerides was also observed $(\mathrm{p}<0.05$ vs. the animals investigated at two days) (Table 1). A triglyceride-deposit positive case is seen in Figure 1. No significant differences in plasma glucose, triglyceride, or NEFA values were found between two and three days after the induction of streptozotocin, but between two and four days the difference between plasma glucose levels was significant, as was the difference between plasma NEFA values. 


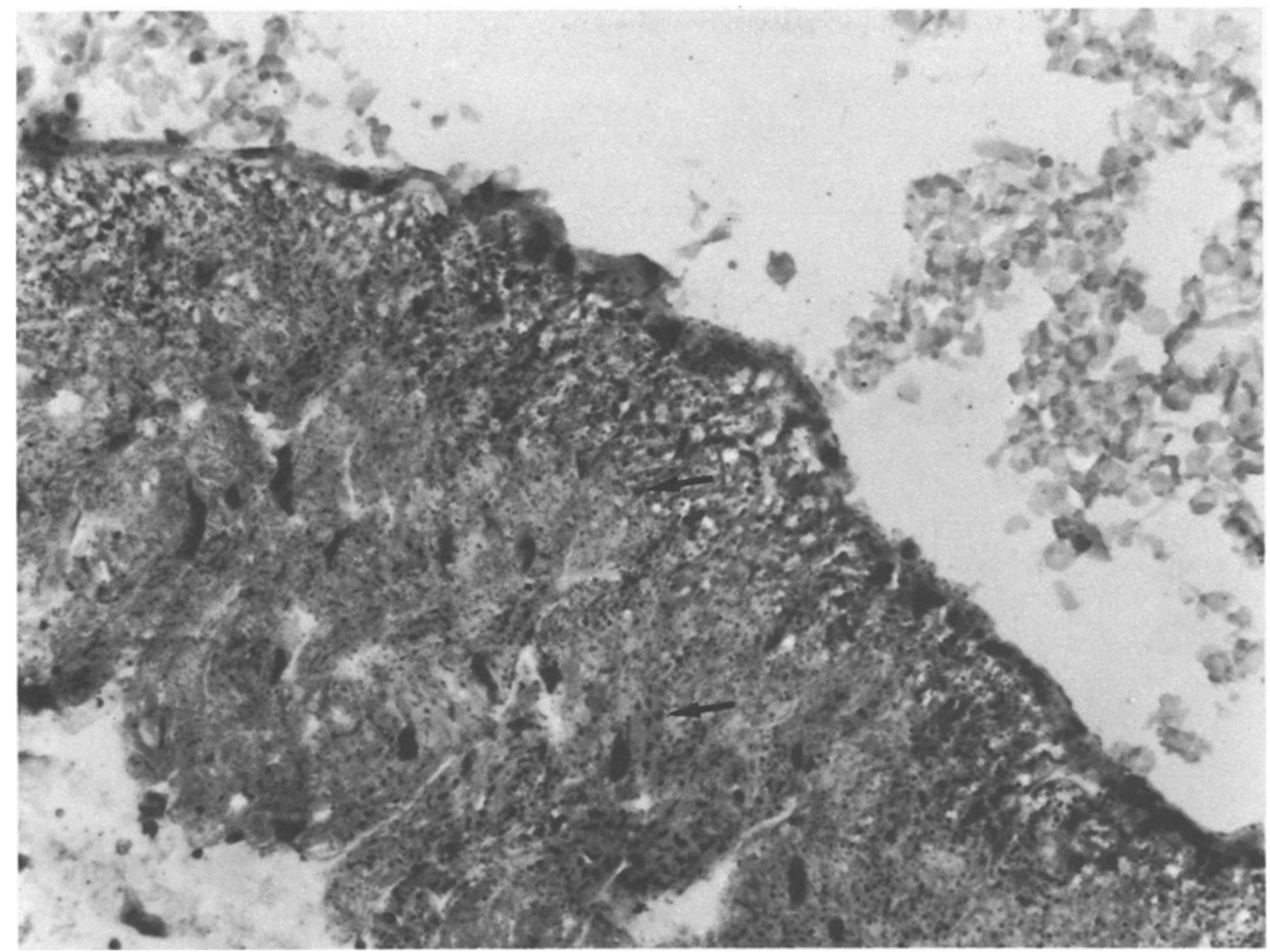

Fig. 1. Triglyceride deposits $(\leftarrow)$ in the wall of the pulmonary artery of a diabetic rat, not treated with insulin. The deposits are mostly located in the media (lead-lipase sulphide, original magnification $\times 380$ )

\section{Influence of Insulin Treatment}

Control of Diabetes: Fourteen days after the initiation of insulin treatment all of the diabetic rats had reached their pre-treatment weight $(329 \pm 4.6 \mathrm{~g}$ vs. $322 \pm 3.5 \mathrm{~g}$, respectively). The plasma glucose and lipid values, and the glucosuria and ketonuria readings two, five, nine and 14 days after the start of insulin treatment are shown in Table 2.

Insulin treatment restored plasma lipid values to the normal range within two days $(p<0.001)$. Variance analysis showed the plasma lipid values of the diabetic rats, treated with insulin for two days or longer, to be similar to those of the control rats (variance ratios ranging from 0.21 to 2.10 ).

Normoglycaemia and aglucosuria were achieved within five and elimination of ketonuria within two days.

Deposition of Triglycerides in the Pulmonary Artery: Triglyceride deposits in the pulmonary artery wall were seen in one of the 15 diabetic rats treated with insulin for two days. Plasma NEFA in this animal were $0.37 \mathrm{mmol} / \mathrm{l}$, triglycerides $141 \mathrm{mg} / 100 \mathrm{ml}$, plasma glucose $136 \mathrm{mg} / 100 \mathrm{ml}$, and there was no ketonuria. No triglyceride deposits were observed in any of the rats treated with insulin for five, nine or 14 days. A triglyceride deposit-negative case in shown in Figure 2.

Lipid Composition of the Pulmonary Tissue: The elevated content of NEFA and triglycerides, and the decreased concentration of phospholipids of the pulmonary tissue were normalized in the diabetic rats treated with insulin for 14 days (Table 3 ) when compared with data obtained from rats not treated with insulin and having a similar severity of diabetes as that of the insulin-treated ones before the start of insulin treatment [5].

\section{Discussion}

In the present study triglycerides accumulated mostly in the media of the pulmonary artery, and insulin 
Table 2. Plasma glucose, triglycerides, non-esterified fatty acids (NEFA), phospholipids, and total cholesterol levels and the averags glucosuria and ketonuria readings four days after the induction of diabetes (streptozotocin $65 \mathrm{mg} / \mathrm{kg}$ ), and after insulin treatment $\mathrm{o}$ diabetic rats, and in non-diabetic control rats

\begin{tabular}{|c|c|c|c|c|c|c|c|c|}
\hline & \multicolumn{5}{|l|}{ Diabetic rats } & \multirow{3}{*}{$\begin{array}{l}\text { Control rats } \\
\text { No insulin } \\
\text { treatment }\end{array}$} & \multirow{3}{*}{\multicolumn{2}{|c|}{$\begin{array}{l}\text { Variance } \\
\text { ratio } F \text { and } \\
\text { significance level }\end{array}$}} \\
\hline & \multirow{2}{*}{$\begin{array}{l}\text { Before insulin } \\
\text { treatment }\end{array}$} & \multicolumn{4}{|c|}{ Duration of insulin treatment } & & & \\
\hline & & two days & five days & nine days & $\overline{14 \text { days }}$ & & & \\
\hline Group & I & II & III & IV & $\mathrm{V}$ & VI & \multirow{2}{*}{ I-VI } & \multirow[t]{2}{*}{ II-V] } \\
\hline $\mathbf{n}$ & 19 & 15 & 15 & 15 & 19 & 19 & & \\
\hline \multirow{2}{*}{$\begin{array}{l}\text { Plasma glucose } \\
(\mathrm{mg} / 100 \mathrm{ml})\end{array}$} & \multirow[t]{2}{*}{325} & \multirow[t]{2}{*}{141} & \multirow[t]{2}{*}{94} & \multirow[t]{2}{*}{112} & \multirow[t]{2}{*}{102} & \multirow[t]{2}{*}{97} & 25.7 & 4.2 \\
\hline & & & & & & & $0.1 \%$ & $1 \%$ \\
\hline \multirow{2}{*}{$\begin{array}{l}\text { Plasma triglycerides } \\
(\mathrm{mg} / 100 \mathrm{ml})\end{array}$} & \multirow[t]{2}{*}{930} & \multirow[t]{2}{*}{121} & \multirow[t]{2}{*}{146} & \multirow[t]{2}{*}{171} & \multirow[t]{2}{*}{180} & \multirow{2}{*}{160} & 18.5 & 2.1 \\
\hline & & & & & & & $0.1 \%$ & NS \\
\hline \multirow[t]{2}{*}{ Plasma NEFA (mmol/l) } & \multirow[t]{2}{*}{1.20} & \multirow[t]{2}{*}{0.46} & \multirow[t]{2}{*}{0.50} & \multirow[t]{2}{*}{0.49} & \multirow[t]{2}{*}{0.55} & \multirow[t]{2}{*}{0.45} & 7.2 & 0.2 \\
\hline & & & & & & & $0.1 \%$ & NS \\
\hline \multirow{2}{*}{$\begin{array}{l}\text { Plasma phospholipids } \\
(\mathrm{mg} / 100 \mathrm{ml})\end{array}$} & \multirow[t]{2}{*}{230} & \multirow[t]{2}{*}{130} & \multirow[t]{2}{*}{120} & \multirow[t]{2}{*}{132} & \multirow[t]{2}{*}{124} & \multirow[t]{2}{*}{125} & 8.0 & 0.4 \\
\hline & & & & & & & $0.1 \%$ & NS \\
\hline Plasma total chole- & 120 & 85 & 81 & 75 & 73 & 70 & 11.2 & 0.9 \\
\hline sterol $(\mathrm{mg} / 100 \mathrm{ml})$ & & & & & & & $0.1 \%$ & NS \\
\hline Glucosuria $\mathrm{g} / 100 \mathrm{ml}$ & 5 & 2 & 0 & 2 & 0 & 0 & & \\
\hline Ketonuria & +++ & - & - & - & - & - & & \\
\hline
\end{tabular}

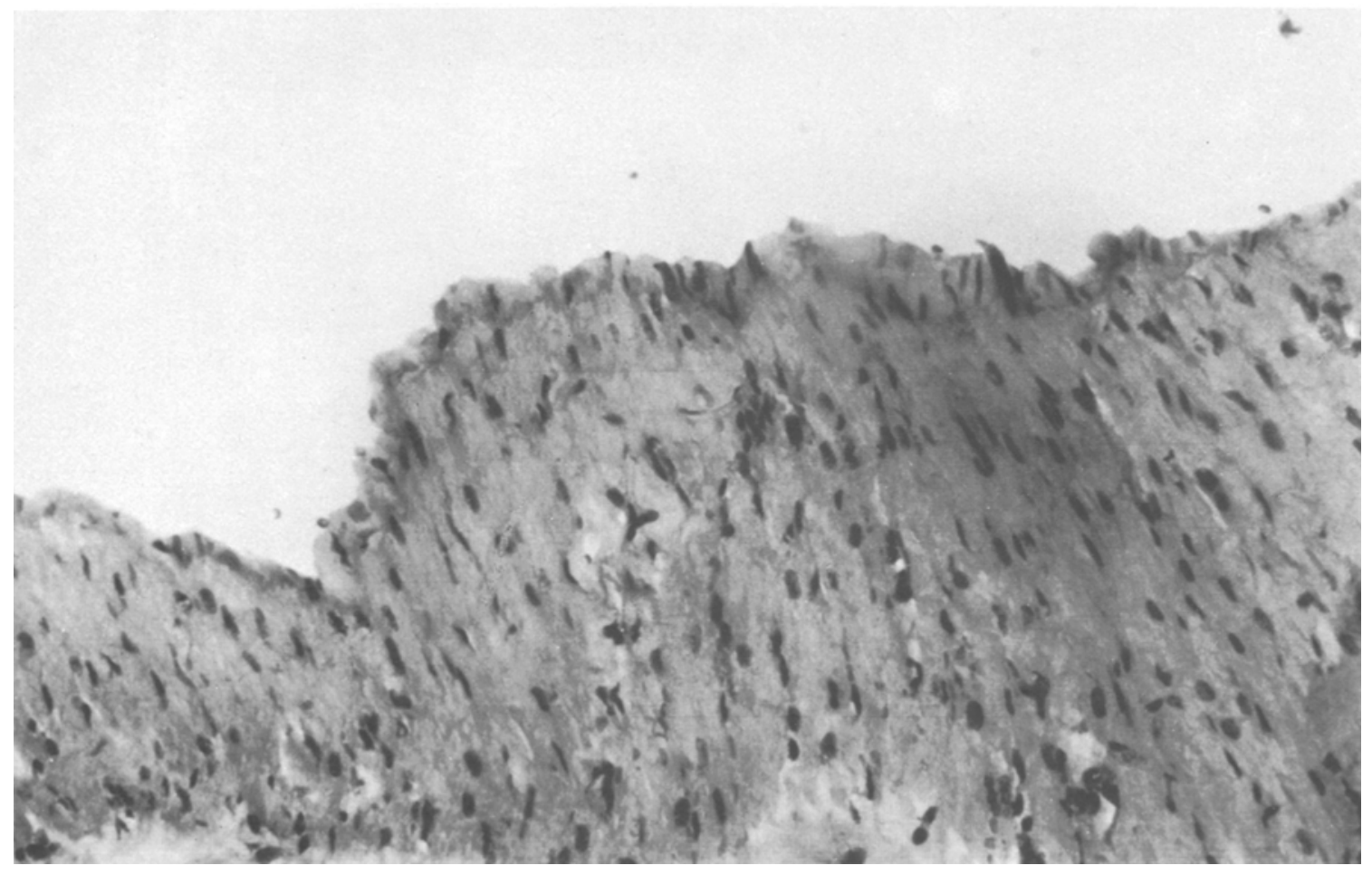

Fig. 2. The wall of the pulmonary artery of a diabetic rat, treated with insulin for nine days. No triglyceride deposits are seen (lead-lipast sulphide, original magnification $\times 230$ )

treatment removed the deposits within a few days. No final conclusions can be made about the precise mechanism for the disappearance of triglyceride deposits after insulin treatment. It is possible that triglyceride accumulation is due to hypertriglyceridaemia, resulting from depressed LPL activity in insulin deficiency $[22,23]$, the triglycerides being transported in plasma lipoproteins into the arteria wall [24]. However, our present and previous find ings [5] do not show any clear differences in plasm: triglyceride concentrations between triglycerids deposit-positive and -negative cases. Therefore 
Table 3. The level of triglycerides, non-esterified fatty acids (NEFA), phospholipids and total cholesterol in the pulmonary tissue of diabetic rats not treated with insulin, of diabetic rats treated with insulin for 14 days, and of the non-diabetic control rats (mg/g of total lipids)

\begin{tabular}{|c|c|c|c|c|c|}
\hline $\begin{array}{l}\text { Lipids in the pulmonary } \\
\text { tissue } \\
n\end{array}$ & $\begin{array}{l}\text { Diabetic rats not } \\
\text { treated with insulin } \\
43\end{array}$ & $\begin{array}{l}\text { Diabetic rats } \\
\text { treated with insulin } \\
19\end{array}$ & $\begin{array}{l}\text { Control } \\
\text { rats } \\
19\end{array}$ & $\begin{array}{l}\text { Variance } \\
\text { ratio } F\end{array}$ & $\begin{array}{l}\text { Level of } \\
\text { significance, \% }\end{array}$ \\
\hline \multicolumn{6}{|l|}{$m g / g$ of total lipids } \\
\hline Triglycerides & 187 & 147 & 151 & 3.1 & $5-10$ \\
\hline NEFA & 159 & 110 & 116 & 16.8 & 0.1 \\
\hline Phospholipids & 536 & 634 & 628 & 13.1 & 0.1 \\
\hline Total cholesterol & 118 & 109 & 107 & 0.9 & NS \\
\hline
\end{tabular}

a Reinilä, A., Koivisto, V. A., Åkerblom, H. K.: Diabetologia 13, 305-310 (1977)

other mechanisms than hypertriglyceridaemia could also be responsible for triglyceride deposition into the arterial wall during insulin deficiency. The possible role of increased plasma NEFA and glucose levels should not be overlooked.

It is generally assumed that the increased risk of atherosclerosis in diabetes is mediated by high plasma lipid levels, especially those of cholesterol and triglycerides. Some observations, however, suggest that in the diabetic state some factor other than high serum lipid levels might cause atherosclerosis $[25,26]$. The tendency to atherosclerosis in diabetes should perhaps also be considered separately depending on whether insulin therapy has been given or not. Further studies are evidently required for the evaluation of the significance of the pulmonary artery triglyceride deposits in the pathogenesis of atherosclerosis, and of the probable particular role of the pulmonary artery in this respect.

Glucose is an important substrate for lung tissue, e. g. as a precursor for lipid synthesis. Physiological concentrations of insulin in the in situ rat lung preparation have a clear and significant effect on glucose metabolism [27], suggesting that the lungs may also have an essential non-respiratory metabolic function. It has been proposed that both glucose transport and utilization are reduced during insulin deprivation [28]. Too much insulin is not good for the lungs, since hyperinsulinaemia may impair phospholipid synthesis by reducing dihydroxy-acetone phosphate and glycerol-3-phosphate production, thus causing decreased synthesis of surfactant. The infants of diabetic mothers often have hyperinsulinaemia, and this state may be responsible for the increased frequency of respiratory distress syndrome in these infants [29].

In the present study insulin therapy of diabetic rats restored the decreased concentration of pulmonary phospholipids, the finding corroborating that made previously by others $[6,7]$. The increased content of NEFA and triglycerides, and the slightly elevated total cholesterol content in the pulmonary tissues were also normalized with insulin therapy, confirming that lung tissue of the diabetic rat readily reacts to the correction of insulin deficiency.

In addition to the disturbed lipid metabolism of the lungs in diabetes, some changes of lung elasticity in juvenile diabetics have been reported, suggesting abnormalities in elastin and collagen [30]. On the other hand, another group has reported that lung function tests in juvenile diabetics are similar to those of age- and sex-matched non-diabetic controls [31].

Thus, data from other laboratories and the present findings suggest that many functions of the lung tissue may be adversely affected during insulin deficiency, and that insulin administration corrects the abnormalities.

Acknowledgements. This study was supported by the Finnish State Medical Research Council (Academy of Finland), the Orion Research Foundation and the Medical Research Foundation of Oulu, Finland (A.R.). The authors thank Associate Professor Jussi K. Huttunen, Professor Esko A. Nikkilä and Dr. Robert $O$. Scow for criticism of the manuscript.

\section{References}

1. Parkes, A. P., Mahler, R. F.: The nature of pig arterial lipase. Atherosclerosis 20, 281-286 (1974)

2. Dicorleto, P. E., Zilversmit, D. B.: Lipoprotein lipase activity in bovine aorta. Proc. Soc. Exp. Biol. Med. 148, 1101-1105 (1975)

3. Mahler, R.: The effect of diabetes and insulin on biochemical reactions of the arterial wall. Acta Diabetol. Lat. 8, 68-83 (1971)

4. Chmelař, M., Chmelarová, M.: Lipolytic effect of insulin and other hormones in vitro in aortic tissue of experimental animals. Experientia 24, 1118-1119 (1968)

5. Reinilä, A., Koivisto, V. A., Åkerblom, H. K.: Lipids in the pulmonary artery and the lungs of severely diabetic rats: a histochemical and chemical study. Diabetologia 13, 305-310 (1977)

6. Moxley, M. A., Longmore, W. J.: Studies on the effects of alloxan and streptozotocin induced diabetes on lipid metabolism in the isolated perfused rat lung. Life Sci. 17, 921-926 (1975) 
7. Moxley, M. A., Longmore, W. J.: Effect of experimental diabetes and insulin on lipid metabolism in the isolated perfused rat lung. Biochim. Biophys. Acta 488, 218-224 (1977)

8. Rönning, O., Isotupa, K.: A method for intracardial injections on rats. Anat. Rec. 158, 245-248 (1967)

9. Mallory, F. B.: Pathological technique, p. 118. Philadelphia: W. B. Saunders 1942

10. Holczinger, L.: Histochemischer Nachweis freier Fettsäuren. Acta Histochem. (Jena) 8, 167-175 (1959)

11. Adams, C.W.M., Abdulla, Y.H., Bayliss, O. B., Weller, O. R.: Histochemical detection of triglyceride esters with specific lipases and calcium lead sulphide technique. J. Histochem. Cytochem. 14, 385-395 (1966)

12. Weber, A. F., Phillips, M. G., Bell, J. T.: An improved method for the Schultz cholesterol test. J. Histochem. Cytochem. 4, 308-309 (1956)

13. Adams, C. W. M.: Osmium tetroxide- $\alpha$-naphthylamine (OTAN) method for phospholipids, cholesterol esters and triglyceride esters. In: Neurohistochemistry. Adams, C. W. M. (Ed.), pp. 55-56. Amsterdam: Elsevier 1965

14. Folch, J., Lees, M., Sloane Stanley, G. H.: A simple method for isolation and purification of total lipids from animal tissues. J. Biol. Chem. 226, 497-509 (1957)

15. Sperry, W.M.: Gravimetric determination of total lipids in blood serum or plasma. In: Standard methods of clinical chemistry. Seligson, D. (Ed.), 4th ed., pp. 173-182. New York: Academic Press 1963

16. Dole, V.P.: A relation between non-esterified fatty acids in plasma and the metabolism of glucose. J. Clin. Invest. 35, 150-154 (1956)

17. Eggstein, H., Kreutz, F. H.: Eine neue Bestimmung der Neutralfette im Blutserum und Gewebe. Klin. Wochenschr. 44 262-267 (1966)

18. Wybenga, D. R., Pileggi, V. J., Distine, P. H., Di Giorgio, J.: Direct manual determination of serum total cholesterol with a single stable reagent. Clin. Chem. 16, 980-984 (1970)

19. Zilversmit, D. B., Davis, A. K.: Microdetermination of plasma phospholipids by trichloroacetic acid precipitation. J. Lab. Clin. Med. 35, 155-157 (1950)

20. Carrol, J. J., Smith, N., Babson, A. L.: A colorimetric serum glucose determination using hexokinase and glucose-6-phosphate dehydrogenase. Biochem. Med. 4, 171-180 (1970)

21. Coburn, H. J., Carrol, J. J.: An improved manual and automated colorimetric serum glucose determination using hexokinase and glucose-6-phosphate dehydrogenase. Clin. Chem. 19, 127-130 (1973)
22. Reaven, E. P., Reaven, G. M.: Mechanisms for development of diabetic hypertriglyceridemia in streptozotocin-treated rats. Effect of diet and duration of insulin deficiency. J. Clin. Invest. 54, 1167-1178 (1974)

23. Nikkilä, E. A., Huttunen, J. K., Ehnholm, C.: Postheparin plasma lipoprotein lipase and hepatic lipase in diabetes mellitus. Relationship to plasma triglyceride metabolism. Diabetes 26, 11-21 (1977)

24. Parker, F., Bagdade, J. D., Odland, G. F., Bierman, E. L.: Evidence for the chylomicron origin of lipids accumulating in diabetic eruptive xanthomas: a correlative lipid biochemical, histochemical and electron microscopic study. J. Clin. Invest. 49, 2172-2187 (1970)

25. Nikkilä, E. A., Hormila, P.: Coronary heart disease and its risk factors among chronic insulin dependent diabetics. Diabetologia 12, 412-413 (1976)

26. Nikkilä, E. A., Hormila, P., Huttunen, J. K.: Increase in high density lipoprotein levels and of postheparin plasma lipoprotein lipase activity in insulin treated diabetics. Circulation 56, III-23 (1977)

27. Stubbs, W. A., Morgan, I., Lloyd, B., Alberti, K. G. M. M.: The effect of insulin on lung metabolism in the rat. Clin. Endocrinol. (Oxf.) 7, 181-184 (1977)

28. Morishige, W. K., Uetake, C-A., Greenwood, F. C., Akaka, J.: Pulmonary insulin responsivity: In vivo effects of insulin on the diabetic rat lung and specific insulin binding to lung receptors in normal rats. Endocrinology 100, 1710-1722 (1977)

29. Stubbs, W. A., Stubbs, S. M.: Hyperinsulinism, diabetes mellitus, and respiratory distress of the newborn: A common link? Lancet 1978 I, 308-309

30. Schuyler, M. R., Niewoehner, D. E., Inkley, S. R., Kohn, R.: Abnormal lung elasticity in juvenile diabetes mellitus. Am. Rev. Respir. Dis. 113, 37-41 (1976)

31. Schernthaner, G., Haber, P., Kummer, F., Ludwig, H.: Lung elasticity in juvenile-onset diabetes mellitus. Am. Rev. Respir. Dis. 116, 544-546 (1977)

Received: May 16, 1978,

and in revised form: August 31, 1978

A. Reinilä, M. D.

Department of Pathology

University of Oulu

Kajaanintie $52 \mathrm{D}$

SF-90220 Oulu 22

Finland 